\title{
Family Firm and Capital Expenditure
}

\author{
Ardiansyah Rasyid ${ }^{1 *}$, Viter Pratama $^{1}$ \\ ${ }^{1}$ Faculty of Economics and Business, Universitas Tarumanagara, Jakarta, Indonesia \\ ${ }^{*}$ Corresponding author. Email: ardiansyahr@fe.untar.ac.id
}

\begin{abstract}
This paper aimed to investigate that the family ownership affects capital expenditure. This phenomenon can be indicated by firm financing, which is related to the sales and cash flow factors. Family ownership aims to defend the capital aggressiveness as reflected by the capital expenditure activity. Data was obtained from public companies listed in the Indonesia Stock Exchange (IDX) in the period of 2014-2016. Data analysis used multiple regression model. The result of this research is that cash flow and family ownership do not influence capital expenditure positively. But for the other variable; sales positively influence capital expenditure. From this result, this paper does not indicate that family ownership finances the capital expenditure more aggressively. The data cannot approve that family ownership can control capital expenditure and also the cash flow variable cannot prove the pecking-order theory. However, sales variable can influence capital expenditure as a base of financing. This phenomenon can support the pecking-order theory. This means that sales variable can finance the capital expenditure, which finally can reduce the agency cost.
\end{abstract}

Keywords: Capital expenditure activity, family ownership, pecking-order theory, agency cost

\section{INTRODUCTION}

Family firm is still an interesting topic to be studied as part of the economic phenomenon. These kinds of business arrange expected performance standards and provide the experience and phenomenon history to be studied for broader business community. A family firm is a film whose financial performance is managed and supervised by two or more family members [1] [2] [3].

The survey conducted by Pricewaterhouse in 2014 stated that more than $95 \%$ of businesses in Indonesia were owned by families and $60 \%$ of public firms in Southeast Asia are family firms [14].

Regarding the ownership structure that is concentrated in the family, it is very possible for the agency problems to arise from the use of internal funds. This is a problem caused because the ownership of a corporation is concentrated in a family. Therefore, there are different interests among the groups with small portion of shares and those with majority shares (family) to take actions that can harm the minority shareholders. In fact, many family firms have the majority rights in managerial activities in the firms. The majority shares owned by an individual or a certain group, will have sufficient voting rights to have control over the firm's management. Family has an influence on capital expenditure as reflected in the share ownership by individuals or a certain group that can enhance the firm's decision.

Family owners can be a representative of majority shareholders that maintain undiversified or concentrated shares ownership in a single firm [5]. Meanwhile, [6] observed that large, undiversified shareholders may force the firm to seek low-risk projects and avoid high-risk activities, thereby imposing costs on well-diversified external shareholders. Family firms tend to avoid higher risk, because they don't want to be high-risk taker, or in other word, they would like to take conservative position. Based on the background and problem identification, the problem formulations of this research are: (1) Does cash flow positively influence capital expenditure? (2). Does sales positively influence capital expenditure? (3). Does family ownership negatively influence capital expenditures?

\section{THEORETICAL AND LITERATURE REVIEW}

\subsection{Agency Theory}

Agency theory is based on the principal-agent relationship, which is the owner-manager relationship in the family business context. It mentions that individuals are driven by economic motive; they behave in opportunistic ways and work in order to maximize their-own returns even at the cost of causing damage / loss to the organization, which is known as the agency cost. The agency theory perspective suggests family firms to shape the governance mechanisms structure that monitor and incentivize for checking of opportunistic behavior, shirking responsibility, or freeriding. This minimizes the agency costs, thereby improves firm performance. On the other hand, stewardship theory is based on the humanistic model, which considers managers as stewards with intrinsic desire to serve the firm and hence, naturally align with the principal (owner). They work in a pro-organizational and collective manner that serve the interests of all stakeholders. Stewardship theory suggests 
the governance mechanisms based on trust that cooperate and involve everyone so that a natural alignment of the manager and the owner can be achieved. This leads to wealth maximization, thereby contributes to firm performance.

Agency theory is a theory that explains the existence of conflict between management and shareholders or owners. The conflict that arises between management and shareholders is the difference in interests between those two parties. This conflict arises when the management uses the fund for capital expenditure.

It can be concluded that the corporate ownership owned by individual or group with a sufficiently-large percentage will have a chance in placing a member on Board of Directors. Therefore, this can become a seed for action that can benefit themselves in form of aggressive investment, and [4] has found that there is a positive relationship between cash flow and investment which can be an indication of agency actions towards the use of cash flow. On the other side, the negative relationship between cash flow and capital expenditure provides the information that a member of Board of Directors acts as a steward which emphasizes the interests of shareholders.

\subsection{Pecking-Order Theory}

Sales serve as an indicator to finance all firm's operations that can be cheaper than other sources of finance. The increase of sales can generate more profit, then a firm can have internal fund (Pecking-Order Theory) and related to the statement of [4]: "The level of sales reflects future expectations and capacity utilization". It can be inferred that the level of sales can be used for forecasting future sales and whether the normal capacity for engine production can meet the production expectations. The limited production of a manufacturing firm is very dependent on the capacity of fixed assets in form of machinery used, with a constraint that the machine has limitations in making production. With the tendency to sales increase, the managers' expectations to the commodity amount produced by the firm tend to increase as well, which would cause the machines to brakedown due to having limited capacity. Consequently, managers will consider capital expenditures, especially for machinery or other fixed-assets that will encourage the increase of production capacity.

\subsection{Agency Theory as Connected to Relationship between Family Ownership and Capital Expenditure}

With the existence of family ownership in a firm, there is an indication that the family has a stake in decision making and has a controlling role in the decision that will be taken by the firm. Then, it can be assumed that if someone has control over a firm, he or she has a role in making policy regarding the future of the firm. Some managers coming from family (majority shareholders) will determine the policies that will be applied to the firm. The family ownership can have control of the firm, hence, there is an implication of family ownership as majority ownership to the relationship between cash flow as a source of financing and capital expenditure. Cashflow is a source of fund used by managers to invest in the firm's fixed assets. In a familyowned firm, managers are appointed by some directors who are the representatives of majority shareholders who generally have a stake in planning how the firm will use its internal funds (cash flow) for its investment purposes. The use of this fund is according to their needs, if the manager has a common goal with all shareholders. Otherwise, if the manager has his or her own interests, this condition will be able to make the manager overinvest.

\subsection{Relevant Research}

In addition, the literature review and previous research explain the positive and significant influence of cash flow and sales on capital expenditure [4]. Unfortunately, for the other variable (family ownership) does not have significant influence on capital expenditure. On contrary with this research, Tran and Le [6] found that cash flow and sales do not significantly affect capital expenditure. This research was based on this literature, and it is interesting for the Authors to conduct this research.

\subsection{Hypothesis Development}

Cashflow is a funding source owned by a firm, which is generated from the firm's operational activities. The level of cash flow is measured by the income plus the depreciation in the current year which reflects the amount of cash circulating in the firm. Managers will make decisions regarding the source of fund that will be used to finance the capital expenditure for fixed assets which generally have big values. Firms with the ability to generate high profits will tend to use internal funding by converting their high profits into cash flow. On contrary, firms that do not have the ability to generate high profits, will make funding from external parties. Cash flow is used by managers as the main source of capital expenditure related to the addition of firm's assets in achieving the firm's production targets. Based on this explanation, cash flow positively influences capital expenditure. This indicates that managers have the tendency to use the internal fund than the outside fund. Thus, the first hypothesis can be developed as follow: $\mathrm{H}_{1}=$ Cash Flow positively influences Capital Expenditure

The relationship between sales and capital expenditure is found in the sales forecasting by managers, in which sales value that has already occurred in the previous financialyear will be the basis for the firms or managers to estimate that sales increase in the next financial-year will be likely to occur. The increase in sales will have an impact on the increase of the firm's fixed assets. This is based on the fact that each asset is used to support the production capacity. A firm has a limit on the amount of production or commonly known as normal capacity. The increase in number of sales should also be offset by an increase in the amount of investment which reflects the limitation of fixed assets. The 
limited production capacity of an asset will have a negative influence on the productivity level of a firm. Therefore, the option is to buy the new fixed assets to compensate the increase of production in order to meet high expectations of demand during the next financial-year. Thus, the second hypothesis can be developed as follow:

$\mathrm{H}_{2}=$ Sales positively influences Capital Expenditure

Family is a dummy variable used by researchers to indicate whether a firm is owned by a particular organization or individual who is not a government or financial corporation, in which the percentage of ownership is at least $20 \%$. The relationship between family and capital expenditure is reflected by the presence of managers who are agents of majority shareholders who have a negative influence on investment sensitivity in a firm. The existence of agents from majority shareholders will also have an influence on the investment policies of a firm. Generally, the majority shareholders having negative influence on the firm will have their own interests and agents as an extension of their hands. The firm's policies are made by managers who can influence the firm's investment plan with the aim to reduce the investment amount.

$\mathrm{H}_{3}$ = Family Ownership negatively influences Capital Expenditure

The negative and significant influence of family ownership on capital expenditure, which was indicated by the level of corporate ownership dominated by the family (concentrated ownership), tend to conduct conservative investment. This condition will provide a policy that influences the funding of a firm. With the presence of significant family ownership among shareholders, these parties generally have an important position in the managerial arrangement. The presence of concentrated agents from the shareholders will influence the funding policies for investment. Investment funding can be done by using the fund within or inside the firm. The presence of significant shareholders' agents gives an indication that the family has an influence on the use of internal fund, because they think that the fund is less risky than that from outside the firm. Hence, the family will have an influence on the policy that affect the use of internal fund in the firm. Internal fund is like a family's capital that can be transferred to finance the capital expenditure in order to fulfil the big amount of fund needed for financing capital assets [7].

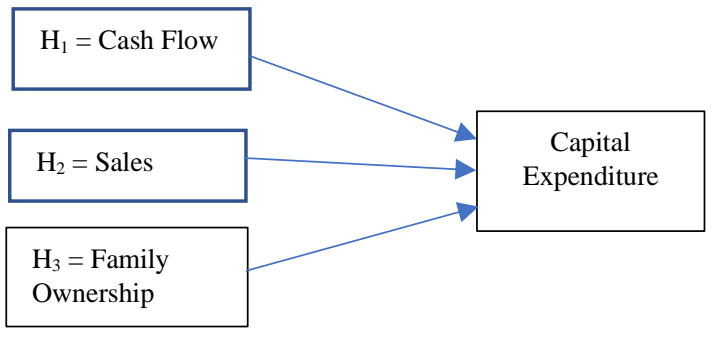

The equation for this model is as follow:

$Y_{t}=\alpha+\beta_{1} X_{1 t-1}+\beta_{2} X_{2 t-1}+\beta_{3} X_{3 t-1}+_{+} e$

$Y_{\mathrm{t}}=$ Capital Expenditure in the current year

$\mathrm{X}_{1 \mathrm{t}}=$ Cash Flow in the current year

$\mathrm{X}_{2 \mathrm{t}}=$ Sales in the current year

$\mathrm{X}_{3 \mathrm{t}}=$ Family Ownership in the current year

$\alpha=$ Constant

$\beta_{1}, \beta_{2}, \beta_{3}=$ Regression Coefficient

$\mathrm{e}=$ Error

\section{RESEARCH METHOD}

\subsection{Data Collection}

Data was collected from Indonesia Stock Exchange (IDX) and then proceeded to the test of three different proposed hypotheses. First, for the dependent variable of this model, we calculated the capital expenditure (Capex ${ }_{i t}$ ). The firm's capital expenditure was computed by adding the expenditure for financing capital assets for the current year or the increase / decrease in net-fixed assets, which is the dependent variable. Second, the Cash Flow (CFit) data was computed as an independent variable. We added back the depreciation expenses to net income in calculating the cash flow proxy, which is being used in the entire set of this model. Third, firm sales were calculated as a proxy for revenues. Last, we needed the financial reportings and annual reports of the firms to calculate a set of control variables for family ownership. As a consequence, the main source of our information is the annual report, including financial reporting such as the statement of financial position, profit and loss statement, cash flow statement, which was extracted from the particular websites of the firms that were available. The time frame is from the year 2014 to 2016, and they provided comprehensive data about firms, banks, insurance companies, mutual funds, etc. They have been excluded from the requirements in order to test the hypotheses of the proposed models within the time span of the analysis. Consequently, the period of this study ranges from the year 2014 to 2016. This three-year period is sufficient for a comprehensive analysis of the firms for long-run (three years).

\subsection{Definition of Dummy Variables}

Two threshold points $25 \%$ and $50 \%$ were used to classify the family ownership and non-family ownership. The $25 \%$ cut-off point was proposed in the official definition of the Group of Owner-Managed and Family Enterprises (GEEF, March, 2008). In this study, both cut-off points were used to differentiate between the family and non-family enterprises, as well as to estimate all proposed models for empirical analysis of each classification in order to obtain the robust and reliable results.

Figure 1 Research Model 


\subsection{The Operationalization of Variables}

The variables analyzed in this study consist of three independent variables and one dependent variable. The independent variable is a variable that affects the dependent variable, whereas the independent variables in this study are internal funding (internal cash flow), sales volume (sales), and family ownership. Meanwhile, the dependent variable is capital expenditure. The calculation of capital expenditure, as proxied by Investment to Total FixedAssets [4], and according to Kim [9], Capex is proxied by investment.

\section{$\frac{\text { Investment }_{i, t}}{\text { Total Fixed Assets }}$}

Internal cash flow is the cash inflow which comes from the internal source, while cash outflow is the cash required for conducting payments [9], as proxied by Cash Flow to Fixed Assets [10].

$$
\frac{\text { Cashflow }_{i, t}}{\text { Total Fixed } \text { Assets }_{i, t-1}}
$$

The sales volume is proxied by Sales to Total Fixed-Assets [4].

$$
\frac{\text { Sales }_{i, t}}{{\text { Total Fixed } \text { Assets }_{i, t-1}}}
$$

Family Firm, which is a dummy variable, can be measured by using the notation of 1 or 0 , whereas 1 is the indication that the firm is owned by the family, and 0 means that the firm is not owned by the family. The influence of family cash flow becomes a highlight, whether the cash flow generated by a family firm will affect its capital expenditure.

\section{$\frac{\text { Family } i, t}{\text { Total Fixed } \text { Assets }_{i, t}}$}

After identifying all variables in this research, authors proceeded to data analysis process by using the multiple linear-regression model. Therefore, the values should be converted to log number, except for the dummy variable (family ownerhip), in order to smooth the execution of previous model.

Previous Model:

$Y_{t}=\alpha+\beta_{1} X_{1 t}+\beta_{2} X_{2 t}+\beta_{3} X_{3 t}+e$

Current Model:

$Y_{t}=\beta_{0}+\beta_{1} \log X_{1}+\beta_{2} \log X_{2}+\beta_{3} X_{3}+\varepsilon$

$\mathrm{Y}=$ Capital Expenditure

$\log \mathrm{X}_{1}=$ Internal Cash Flow

$\log \mathrm{X}_{2}=$ Sales

$\mathrm{X}_{3}=$ Family Ownership (Dummy)

$\beta_{0}-\beta_{3}=$ Coefficient of Regression $\epsilon=$ Error

\section{RESEARCH RESULTS}

\subsection{Statistical-Test Results}

\subsubsection{The Coefficient of Regression}

Table 4.1 presents the t-Test results for the 4 proposed hypotheses, along with the details as follows:

Table 4.1 t-Test Results

\begin{tabular}{|c|c|c|}
\hline Variable & $\begin{array}{c}\text { Coefficient of } \\
\text { Regression }\end{array}$ & Sig. \\
\hline Cash Flow $\left(\mathrm{X}_{1}\right)$ & -0.136 & 0.040 \\
\hline Sales $\left(\mathrm{X}_{2}\right)$ & 0.312 & 0.000 \\
\hline Family Ownership $\left(\mathrm{X}_{3}\right)$ & -0.324 & 0.000 \\
\hline
\end{tabular}

Source: Data Analysis using SPSS version 23

The result in Table 4.1 indicates a negative and significant influence of cash flow on capital expenditure ( $\mathrm{p}$-value $=$ 0.040). However, this result means that $\mathrm{H}_{1}$ must be rejected, because the result was not positive and significant. The result in Table 4.1 also indicates that sales has a positive and significant influence on capital expenditure ( $\mathrm{p}$-value = 0.000). By this result, therefore, $\mathrm{H}_{2}$ was accepted, which means that sales can influence the capital expenditure positively and significantly. The family ownership variable has a negative and significant influence on capital expenditure, with $\mathrm{p}$-value $=0.000$. This means that $\mathrm{H}_{3}$ was accepted.

\subsubsection{Regression Model Equation}

Based on the data analysis result, the regression model equation can be formulated as follow:

Capex $=-1.116-0.136 \log$ Cash Flow $+0.312 \log$

Sales $-0.324 \log$ Family Ownership $+\epsilon$

\subsubsection{Model-Fit Test}

The test must be done in order to ensure that this model is fit and has no doubt regarding the result. The result of model-fit test can be seen in Table 2 as follow:

Table 4.2 Model-Fit Test Result

\begin{tabular}{|c|c|}
\hline F-Test & Sig. \\
\hline 18.289 & 0.000 \\
\hline
\end{tabular}

The above table means that the model is fit, because the significance value is 0.000 (less than 0.05).

\subsubsection{R-Square Test}

$\mathrm{R}$-test is the correlation test and R-square test is the coefficient-of-determination test, of which the results are presented in Table 4.3 below: 
Table 4.3 Coefficient-of-Determination

\begin{tabular}{|c|c|}
\hline $\mathrm{R}$ & $\mathrm{R}-$ Square \\
\hline 0.436 & 0.190 \\
\hline
\end{tabular}

Source: Data Analysis using SPSS version 23

Based on Table 4.3, this research model can only explain $19 \%$ of the variations in Capital Expenditure. This means that the remaining $81 \%$ of the variations in capital expenditure is explained by other variables that are not included in this study.

\subsection{Analysis and Discussions}

The summary of partial-test result using multiple regression analysis concludes that only the sales variable in this research is similar to the research conducted by [4], concluding that sales has a positive and significant influence on capital expenditure. However, the variable of family ownership has different result from the variable of sales. This means that family ownership has a negative and significant influence on capital expenditure, of which this result is not consistent to our hypothesis in this research [12].

\section{Cash Flow negatively influences Capital Expenditure}

Cash flow or fund in a firm is an alternative funding that can be used by managers to expend the capital expenditures regarding the corporation problem faced by the firm, especifically the financing problem. Based on the detail result of partial-test result, the significance value of the cash flow variable is 0.040 (less than 0.05 ), but the $\beta$ (beta) coefficient of the cash flow is negative. Thus, Hypothesis 1 was not accepted, which means that there is not a positive and significant influence of cash flow on capital expenditure. This result explains that the cash flow available for the firm is inversely proportional to the level of investment made by the firm. Theoretically, this cash flow should positively influence the capital expenditure, just like the available internal funding (Pecking-Order Theory).

\section{Sales positively influences Capital Expenditure}

The higher sales obtained in the previous financial year can predict the number of sales-growth in the future, as sales continues to increase the need of fixed-assets investment, because the use of fixed assets can reduce the production capacity constraint. Based on the summary of partial-test results, the significance value of the sales variable is 0.000 (less than 0.05). This result concludes that Hypothesis 2 was accepted, meaning that there is a positive and significant influence of sales on capital expenditure. This result explains that sales has the ability to determine the tendency to invest in the firm's fixed-assets. The increased tendency to invest in fixed-assets is reflected by the number of previous sales. This is because the previous number of sales can be used as a basis to estimate of the number of sales that will be obtained in the next period. The increase of sales is a strong indication that a firm should take an opportunity to increase its production capacity. This research result is consistent to the research conducted by [4].

3. Family Ownership negatively influences Capital Expenditure

Family ownership has an important role in a firm. This family ownership occurs whenever a firm has more than $20 \%$ of shares owned by individuals or groups. This family ownership has the right to vote on the policies made in the firm. The asset-investment policy is one of the policies that is affected by the family ownership. Based on the summary of partial-test result, the significance value of the family ownership variable is 0.000 (less than 0.05 ). This result concludes that Hypothesis 3 was not accepted, meaning that there is a negative and significant influence of family ownership on capital expenditure, as presented by the value of $\beta$ (beta) of $-0,324$ (negative coefficient). This result explains that the concentrated ownership structure (family ownership) has a very efficient control over the firm's management. This is because the presence of concentrated ownership can reduce the capital expenditure ratio. In practice, concentrated ownership has the opportunity to occupy strategic positions to meet the interests of both individuals and the entire shareholders. The existence of agents of shareholders concentrated in the composition of managers can influence the managerial decisions taken, one of which is how the policies taken related to investment will be applied to meet the demand from public regarding the commodities produced. In addition, managers have a stake in the decision regarding the use of funds to finance the investment in fixed-assets so that the investment decisions become more efficient. The result of this study is inversely proportional to [4] and in accordance with the research by [13]. The possibility of differences between the result of this research and those of previous research occur due to the differences in the sample and research-period.

\section{CONCLUSIONS AND SUGGESTIONS}

Studying the ownership structure in a firm has been largely inspired by the agency theory. This article provides the result that family ownership can act as the controller to influence the capital expenditure. The capital aggressiveness from the agent can be declined by the family ownership structure. On the other side, the effectiveness of financing strategies can be achieved by the externalfinancing source, because this research has proven that the agent prefers to using the external financing which means rejecting the Pecking-Order Theory. Family ownership concentration can influence capital expenditure, but it is not as a basis to decide about the source of financing. The main result indicates that family ownership concentration prefers to using the external source of financing to the internal one. This preference is caused by revenue capacity that looking sales revenue. Logically, the role of family ownership has significant effect on financing control by looking at the sales ability. The family has valuable expertise in running 
the firm and getting involved as the agent. Additionally, this research found that family ownership can be a role for all the monitoring system in order to achieve high performance.

In financing source selection, it does not mean that a family firm prefers using the internal source to the external one. However, this ownership structure may have a mechanism that can be used to reduce the agency costs, such as controlling the capital expenditure. The role of equity ownership by family has a significant influence on financing control. Finally, a major limitation of this article is related to the lack of data on family ownership structure with a share portion higher than $10 \%$. Expectedly, further research should address this limitation, and the research period should be expanded to more than three years.

\section{REFERENCES}

[1] Craig E. Aronoff, John L. Ward, Family-owned businesses: A thing of the past or a model for the future?" First published June 1, 1991 Researches Article. https://doi.org/10.1111/j.17416248.1995.00121.x

[2] Nigel Nicholson. Evolutionary Psychology and Family Business: "A New Synthesis for Theory, Research, and Practice", First Published March 1, 2008 Research Article. https://doi.org/10.1111/j.17416248.2007.00111.x

[3] Timothy G. Habberson, Mary Williams, Ian C. MacMillan. "A unified systems perspective of family firm performance", Journal of Business Venturing, Elsevier, vol. 18(4), pages 451-465, July, 2003. Handle: RePEc:eee:jbvent:v:18:y:2003:i:4:p:451-465

[4] Sitthipongpanich, T. (2017), "Family ownership and free cash flow", International Journal of Managerial Finance, Vol. 13 No.2, 2017, pp.133-148. https://doi.org/10.1108/IJMF-06-2014-0088

[5] Shleifer, A., Vishny, R., 1986. Large shareholders and corporate control. Journal of Political Economy 94, 461-489.

[6] Deangelo, H., Deangelo, L., 2000. Controlling shareholders and the disciplinary role of corporate payout policy. Journal of Financial Economics 56, 153 207.

[7] Tran, Nam Hoai \& Le, Chi Dat., 2017. "Financial conditions and corporate investment: evidence from Vietnam”, Pacific Accounting Review, Vol. 29 (2), Pages 183-203, special issue, DOI: 10.1108/PAR-072016-0066
[8] Gibb Dyer. Practice Insight." Creating, Preserving, and Transferring Family Capital: The keys to family business success", weekly edition Aug' 07, 2019. The Firm Family Institute. https://digital.ffi.org/pdf/ wednesday-edition/2019/august/august-07/creatingpreserving-and-transferring-family-capital-the-keys-tofamily-business-success.pdf

[9] Tae-Nyun Kim, "The impact of cash holdings and external financing on investment-cash flow sensitivity," Review of Accounting and Finance, Emerald Group Publishing, vol. 13(3), pages 251-273, August,2014. Handle: RePEc:eme:rafpps:v:13:y:2014:i:3:p:251-273

[10] Agus Harjito dan Martono. 2012. Manajemen Keuangan. Edisi ke-2, 2012. Ekonisia, Yogyakarta.

[11] Riaz, Y., Shahab, Y., Bibi, R., \& Zeb, S. Investment-cash flow sensitivity and financial constraints: evidence from Pakistan. South Asian Journal of Global Business Research, 5(3), 403-423, 2016 doi: https://doi.org/10.1108/SAJGBR-08-20150054

[12] M Hamidi, N Mansor, R Asid." Capital Expenditure Decisions: A Study of Malaysian Listed Companies Using An Ordered Logistic Regression Analysis", Journal of the Asian Academy of Applied Business. 2017

[13] Requejo I., \& la Torre C., 2011. "Family Control and Investment-Cash Flow Sensitivity: Empirical Evidence from the Euro Zone," Journal of Corporate Finance, Vol. 17 (5): 1389-1409, December, 2011. DOI: $10.1016 /$ j.jcorpfin.2011.07.003

[14] https://www.pwc.com/id/en/publications/

[15] www.idx.co.id

[16] www.sahamok.com 